\title{
Relationship between transfusion of packed red blood cells, plasma free hemoglobin and storage time in patients with severe trauma
}

\author{
S Chacón Alves*, M Chico Fernández, C García Fuentes, A Del Pino Ramírez, N Zurera Plaza, L Umezawa Makikado, \\ E Alted López, JC Montejo González
}

From ESICM LIVES 2015

Berlin, Germany. 3-7 October 2015

\section{Introduction}

Transfusion is a treatment in continuing debate and controversy. In recent years, there has been an increased interest about the "storage lesions" and its possible clinical consequences, and in addition, there has been an increased concern about the effect of the "age" of packed red blood cells.

\section{Objectives}

Determining the influence of the age of the packed cells in stable trauma patients in hemolysis parameters and in the performance of transfusion.

\section{Methods}

Prospective, descriptive, observational study on a cohort of patients with severe trauma, that were admitted more than 72 hours in the ICU of Trauma and Emergency of a high complexity hospital, without active bleeding. November 2012 to January 2014. It was measured hemoglobin (hb), hematocrit (hct), plasma free hemoglobin (fhb) by HemoCue ${ }^{\circledR}$, bilirrubin and LDH before and after transfusion of one packed red blood cells. The attending physician determined the transfusion requirement, individually. We collected data about storage and characteristics of packed red blood cells and their age ("young blood" if it was less than 14 days and "old blood" if it was more than 14 days). Statistical data were analyzed by SPSS 16.0 considering statistically significant at $\mathrm{P}<0.05$.

Hospital Universitario Doce de Octubre, Medicina Intensiva, UCI de Trauma y Emergencias, Madrid, Spain

C 2015 Chacón Alves et al.; This is an Open Access article distributed under the terms of the Creative Commons Attribution License (http://creativecommons.org/licenses/by/4.0), which permits unrestricted use, distribution, and reproduction in any medium, provided the original work is properly cited.

\section{Results}

34 transfusions were performed, with average threshold of $6.8 \pm 0.3 \mathrm{~g} / \mathrm{dl}$ for $\mathrm{hb}$ and $20.3 \% \pm 1.6 \%$ for hematocrit. The most common blood group was the group $\mathrm{O}+$ (56\% of transfusions). The plasma free hemoglobin average pre-transfusion was $0.13 \pm 0.06 \mathrm{~g} / \mathrm{dl}$ compared to $0.19 \pm$ $0.06 \mathrm{~g} / \mathrm{dl}$ post-transfusion $(\mathrm{p}<0.05)$. Increasing bilirrubin level was significant too, with a mean value of pre-transfusion $0.88 \pm 0.90 \mathrm{mg} / \mathrm{dl}$ vs $1.14 \pm 1.17 \mathrm{mg} / \mathrm{dl}$ post-transfusion. The average pre-transfusion LDH was $371.24 \pm$ 197.75 U/L and posttransfusion was $396.39 \pm 199.46 \mathrm{U} / \mathrm{L}$ $(p=0.06)$. These figures vary depending on the age of the blood, with an average increase fhb of $0.057 \pm 0.11 \mathrm{~g} / \mathrm{dl}$ for young blood versus $0.064 \pm 0.062 \mathrm{~g} / \mathrm{dl}$ for old blood $(\mathrm{p}>0,05)$

$\mathrm{Hb}$ performance adjusted to body surface is higher in young versus old blood, with an average of $0.91 \mathrm{~g} / \mathrm{dl}$ per $\mathrm{kg} / \mathrm{m} 2 \pm 0.58$ vs $0,51 \mathrm{~g} / \mathrm{dl}$ per $\mathrm{kg} / \mathrm{m} 2 \pm 0.13$ for $\mathrm{hb}$ and $2.88 \%$ per $\mathrm{Kg} / \mathrm{m} 2 \pm 1.84$ vs $1.57 \%$ per $\mathrm{Kg} / \mathrm{m} 2$ \pm 0.52 for hematocrit $(\mathrm{p}<0.001)$.

\section{Conclusions}

The transfusion of one packed red blood cells increases $\mathrm{BPH}$ and hemolysis significantly. Young blood transfusion has higher performance.

\section{Published: 1 October 2015}

\section{References \\ 1. Holst LB, Petersen MW, et al: Restrictive versus liberal transfusion strategy for red blood cell transfusion: systematic review of randomised trials with meta-analysis and trial sequential analysis. BMJ 2015, 350:1-15. \\ 2. Spinella PC, Carroll CL, et al: Duration of red blood cell storage is associated with increased incidence of deep vein thrombosis and in}


hospital mortality in patients with traumatic injuries. Crit Care 2009, 13:

R15.

3. Aubron C, Nichol A, et al: Age of red blood cells and transfusion in critically ill patients. Ann Intensive Care 2013, 3:2.

doi:10.1186/2197-425X-3-S1-A916

Cite this article as: Chacón Alves et al:: Relationship between transfusion of packed red blood cells, plasma free hemoglobin and storage time in patients with severe trauma. Intensive Care Medicine Experimental 20153 (Suppl 1):A916.

\section{Submit your manuscript to a SpringerOpen ${ }^{\mathcal{O}}$ journal and benefit from:}

- Convenient online submission

- Rigorous peer review

- Immediate publication on acceptance

- Open access: articles freely available online

- High visibility within the field

- Retaining the copyright to your article

Submit your next manuscript at $\gg$ springeropen.com 